\title{
Erosion Wear Behaviour of Copper Slag Filled Short Bamboo Fiber Reinforced Epoxy Composites
}

\author{
Sandhyarani Biswas
}

\begin{abstract}
Recently, the use of natural fiber reinforced composites starts gaining popularity in engineering applications due to the fact that this material possesses characteristics that are comparable to conventional materials. Among natural fibers, bamboo has been widely used for many such applications due to its availability and low cost. Attempts have been made in this paper to explore the potential utilization of bamboo fiber in polymer matrix composites. Due to environmental regulations, new ways of utilizing various metal industry slags are being explored in order to safeguard the environment and to provide useful ways for their utilization and disposal. Copper slag is such an industrial waste which is produced as a by-product during smelting and refining of copper. Rich in various metal oxides, it has tremendous potential to be utilized as a filler material in polymer composites. Therefore, this work is focused on the erosion wear behavior of copper slag filled short bamboo fiber reinforced epoxy composites. It further outlines a methodology based on Taguchi's experimental design approach to make a parametric analysis of erosion characteristics.
\end{abstract}

Index Terms - Copper slag, erosion wear, taguchi method.

\section{INTRODUCTION}

Recently, ecological concerns have resulted in increased interest in natural materials. Issues such as recyclability and environmental safety are becoming increasingly important to the introduction of new materials and products. Natural fibers like flax, hemp, bamboo, banana, sisal, oil palm, and jute have a number of techno-economical and ecological advantages over synthetic fibers like glass fibers. Among various natural fibers, bamboo has been widely used for various applications due to its many advantages. Bamboo abundantly available in India is one of the fastest renewable plants with a maturity cycle of 3-4 years. It has excellent mechanical properties in comparison with its weight due to its longitudinally aligned fibers. The potential utilization of this material in various forms for a wide range of applications has already been explored. However, such superior mechanical properties have not been well drawn for polymer-based composites. The use of bamboo fiber in such products can help to reduce the demand for wood fibers and environmental impacts associated with wood fiber harvesting.

As the scientific advancement has given a boon to the society to generate a large amount of waste, which has now come to a stage for environmental threat and needs disposal

Manuscript received February 12, 2013; revised June 30, 2013

S. Biswas is with the Mechanical Engineering Department, National Institute of Technology, Rourkela-769008, Odisha, India (e-mail: sandhya_biswas@yahoo.co.in) and/or utilization. Over last few decades, intensive research has been carried out to explore all possible reuse methods of a wide range of waste materials. Till now, construction waste, blast furnace and steel slag, coal fly ash and bottom ash, have been accepted in many places as alternative aggregates in embankment, pavement, road, foundation and building construction. Metal industry slag, mine-stone and mining waste are generally suitable for recycling or reuse, and the use of these inorganic wastes as alternative materials in building, road and geotechnical constructions [1]-[4]. Mroueh et al. [5] attempted to carry out life-cycle analysis of the use of metal industry slag in road and earth constructions, and their analysis yielded promising conclusions for the reuse of this type of waste. Copper slag is a by-product obtained during the matte smelting and refining of copper [6]. Production of one ton of copper generates, approximately 2.2-3 tons of copper slag. In the United States, the amount of copper slag produced is about four million tons, and in Japan, it is about two million tons per year [7], [8]. Approximately 360,000, 244,000 and 60,000 tons of copper slag is produced annually in Iran, Brazil and Oman, respectively [9]-[11]. The common management options for copper slag are recycling, recovering of metal, production of value added products such as abrasive tools, roofing granules, cutting tools, railroad ballast and asphalt pavements. However, its use as filler in polymer composites has hardly been reported so far. Using copper slag in polymer composites would possibly provide potential environmental as well as economic benefits for industries, particularly in locations where a considerable amount of copper slag is produced.

The natural fiber reinforced polymer composites are more environmentally friendly, and are frequently used in transportation, military applications, building and construction industries, packaging, and consumer products. Due to the operational requirements in dusty environments, the study of the erosion characteristics of these composites is of high relevance. While a number of research papers on the erosion wear exist in the literature, most of them are confined to fiber reinforced composites [12]-[14]. However, very limited reports are available on both particulate filler and fiber reinforced polymer composites.

Against this background, the present study has been undertaken to explore the development of a new kind of epoxy based composite reinforced with short bamboo fiber and copper slag. Such multi-component hybrid composites form complex systems and there is inadequate data available about phenomena behind their modified wear behaviour due to the presence of both particulate fillers and the reinforcing fibers. In brief, the objective of this study is 
to investigate the suitability of using copper slag as a filler material and to assess its potential in wear related applications.

\section{EXPERIMENTAL DETAILS}

\section{A. Composite Fabrication}

The short bamboo fiber which is taken as reinforcement in this study is collected from local sources. Copper slag collected from the plant site of Hindustan Copper Limited, at Ghatsila, India is sieved to obtain particle size in the range 70-90 $\mu \mathrm{m}$. The epoxy resin and the hardener (HY951) are supplied by Ciba Geigy India Ltd. Moulds having dimensions of $180 \times 180 \times 40 \mathrm{~mm}^{3}$ were used for composite fabrication. The short bamboo fiber and copper slag are mixed with epoxy resin by simple mechanical stirring and the mixture was poured into the moulds. A releasing agent is used on the mould release sheets to facilitate easy removal of the composite from the mould after curing. The entrapped air bubbles (if any) are removed carefully with a sliding roller and the mould is closed for curing at a temperature of $30^{\circ} \mathrm{C}$ for $24 \mathrm{~h}$ at a constant load of $50 \mathrm{~kg}$. Finally, the composites are cut using diamond cutter for further erosion tests. The composition and designation of the composites prepared for this study are listed in the Table I.

TABLE I: DESIGNATION AND COMPOSITION OF THE COMPOSITES

\begin{tabular}{|c|l|}
\hline Designation & \multicolumn{1}{|c|}{ Composition } \\
\hline EBC-1 & Epoxy $(100 w t \%)+$ Bamboo Fiber(0wt\%) \\
\hline EBC-2 & $\begin{array}{l}\text { Epoxy }(50 w t \%)+\text { Bamboo Fiber }(45 w t \%)+\text { Copper slag } \\
(5 w t \%)\end{array}$ \\
\hline EBC-3 & $\begin{array}{l}\text { Epoxy }(45 w t \%)+\text { Bamboo Fiber }(45 w t \%)+\text { Copper slag } \\
(10 w t \%)\end{array}$ \\
\hline EBC-4 & $\begin{array}{l}\text { Epoxy }(40 w t \%)+\text { Bamboo Fiber }(45 w t \%)+\text { Copper slag } \\
(15 w t \%)\end{array}$ \\
\hline
\end{tabular}

\section{B. Erosion Test Apparatus}

A standard erosion test rig (Fig. 1) is used to carry out the solid particle erosion test as per ASTM G76. The test rig consists of an air compressor, an air drying unit, a conveyor belt-type particle feeder and an air particle mixing and accelerating chamber. The dried and compressed air is then mixed with the silica sand which is fed constantly by a conveyor belt feeder into the mixing chamber and then accelerated by passing the mixture through a convergent brass nozzle of $3 \mathrm{~mm}$ internal diameter. The set up is capable of creating reproducible erosive situations for assessing erosion wear resistance of the composite samples. The erodent particles impact the specimen which can be held at different angles with respect to the direction of erodent flow. The velocity of the eroding particles is determined using standard double disc method [15]. The apparatus is equipped with a heater which can regulate and maintain the erodent temperature at any pre-determined fixed value during an erosion trial. The samples are cleaned in acetone, dried and weighed to an accuracy of $\pm 0.1 \mathrm{mg}$ before and after the erosion trials using a precision electronic balance. The weight loss is recorded for subsequent calculation of erosion rate. The ratio of the weight loss to the weight of the eroding particles causing the loss is then computed as a dimensionless incremental erosion rate. The process is repeated till the erosion rate attains a constant value called steady state erosion rate.

EBC: Epoxy-Bamboo Composites

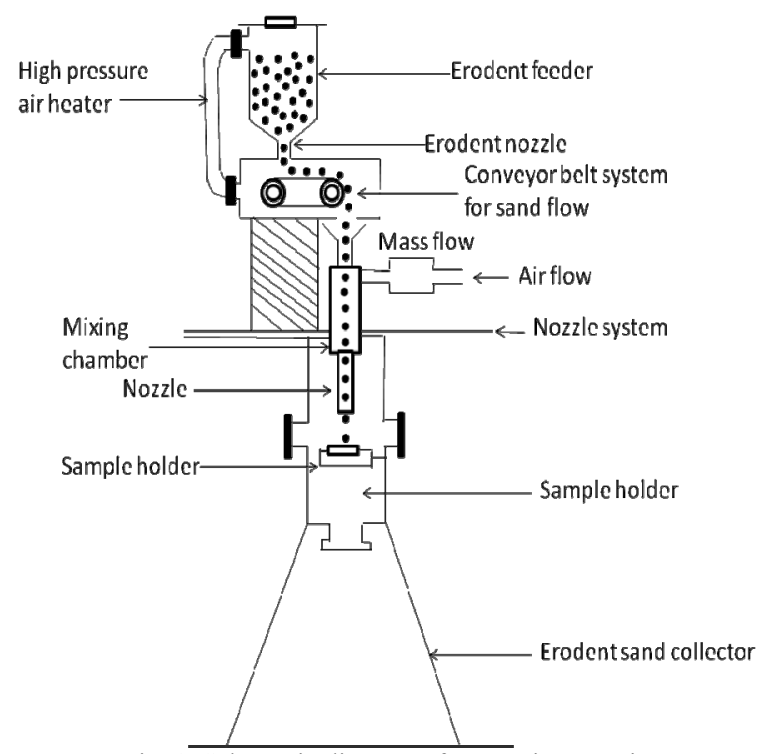

Fig. 1. Schematic diagram of an erosion test rig

\section{Taguchi Experimental Design}

Statistical experimental design methods provide a systematic and efficient plan for experimentation to achieve certain goals so that many control factors can be simultaneously studied. The advantages of using the Taguchi method are that many more factors can be optimized simultaneously and much quantitative information can be extracted by only a few experimental trials. In the present investigation an $\mathrm{L}_{16}$ orthogonal array is used. The parameters used for the experiment are impact velocity, fiber loading/filler content, impingement angle, stand-off-distance and erodent temperature. Table II, indicates the factors and their level.

TABLE II: LEVELS FOR VARIOUS CONTROL FACTORS

\begin{tabular}{|c|c|c|c|c|c|}
\hline \multirow[t]{2}{*}{ Control factor } & \multicolumn{4}{|c|}{ Level } & \\
\hline & I & II & III & IV & Units \\
\hline A: Impact velocity & 35 & 45 & 55 & 65 & $\mathrm{~m} / \mathrm{sec}$ \\
\hline B1: Fiber loading & 0 & 15 & 30 & 45 & wt $\%$ \\
\hline B2: Filler content & 0 & 5 & 10 & 15 & wt $\%$ \\
\hline $\mathrm{C}$ : Impingement angle & 45 & 60 & 75 & 90 & ${ }^{\circ} \mathrm{C}$ \\
\hline D: Stand-off- distance & 55 & 65 & 75 & 85 & $\mathrm{~mm}$ \\
\hline F: Erodent Temperature & 35 & 70 & 105 & 140 & Degree \\
\hline
\end{tabular}

\section{RESUlts AND DiscusSiON}

\section{A. Effect of Impingement Angle on Erosion Rate}

Impingement angle is one of the important parameters for the erosion wear behavior of composite materials. Dependence of erosion rate on the impingement angle is largely determined by the nature of the target material and other operating conditions. In the literature, materials are broadly classified as ductile or brittle, based on the 
dependence of their erosion rate with impingement angle. The ductile behaviour is characterized by maximum erosion rate at low impingement angle i.e. typically in the range of $15^{\circ}<\alpha<30^{\circ}$. On the other hand, if the maximum erosion rate occurs at normal impact $\left(\alpha=90^{\circ}\right)$, the behaviour of material is purely brittle mode. Fig. 2 shows the effect of impingement angle on erosion rate of composites filled with copper slag. It is observed that the peak erosion rates are located at an impingement angle of $60^{\circ}$ for all composite samples. This shows semi-ductile erosion response for the bamboo fiber reinforced composites.

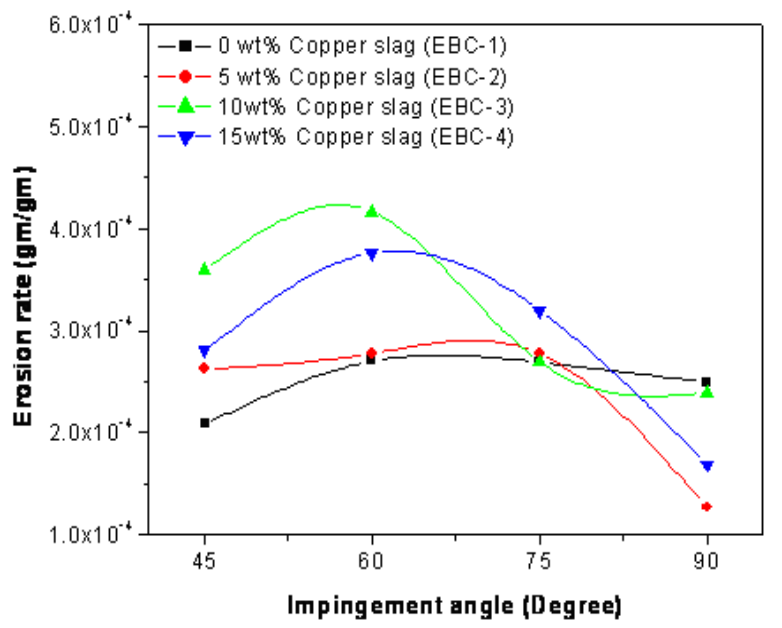

Fig. 2. Effect of impingement angle on erosion rate of copper slag filled composites

\section{B. Effect of Erodent Temperature on Erosion Rate}

The effect of erodent temperature on erosion rate of the bamboo fiber reinforced epoxy composite filled with copper slag is shown in Fig. 3. It is evident from the figure that erosion rate is significantly increasing with the increase of erodent temperature. However, composites with $15 \mathrm{wt} \%$ of copper slag shows minimum erosion rate compared to other irrespective of different erodent temperature.

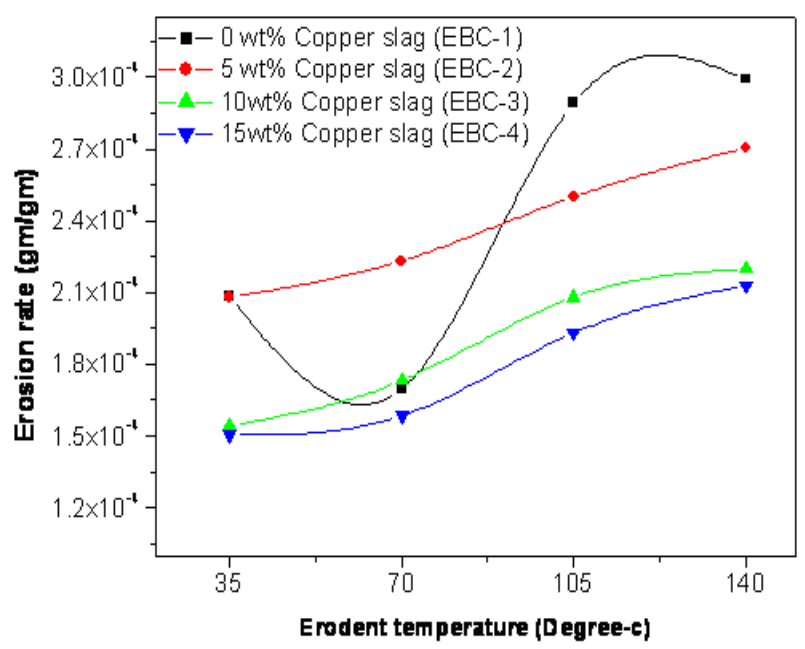

Fig. 3. Effect of erodent temperature on erosion rate of copper slag filled composites

\section{Experimental Analysis}

Table III show the erosion rates of different composites for all 16 test runs and their corresponding $\mathrm{S} / \mathrm{N}$ ratios. Each of the values is in fact the average of two replications. The analysis is made using the popular software specifically used for design of experiment MINITAB 15. Fig. 4 shows graphically the effect of the five factors on erosion rate. From this analysis it is concluded that factor levels $A_{1}, B_{4}$, $\mathrm{C}_{4}, \mathrm{D}_{4}$ and $\mathrm{E}_{3}$ are optimum levels to get minimum erosion rate.

TABLE III: EXPERIMENTAL DESIGN USING L L 16 ORTHOGONAL ARRAY

\begin{tabular}{|c|c|c|c|c|c|c|c|}
\hline Sl. No. & $\begin{array}{l}\text { Impact Velocity } \\
(\mathrm{m} / \mathrm{sec})\end{array}$ & $\begin{array}{l}\text { Fiber loading } \\
\quad(w t \%)\end{array}$ & $\begin{array}{c}\text { Impingement angle } \\
\left({ }^{\circ}\right)\end{array}$ & S.O.D $(\mathrm{mm})$ & Erodent Temp $\left({ }^{\circ} \mathrm{C}\right)$ & Erosion rate $(\mathrm{gm} / \mathrm{gm})$ & S/N Ratio \\
\hline 1 & 35 & 0 & 45 & 55 & 35 & $2.88 \mathrm{E}-04$ & 70.79 \\
\hline 2 & 35 & 5 & 60 & 65 & 70 & $9.9624 \mathrm{E}-06$ & 100.03 \\
\hline 3 & 35 & 10 & 75 & 75 & 105 & $1.5789 \mathrm{E}-05$ & 96.03 \\
\hline 4 & 35 & 15 & 90 & 85 & 140 & $8.6466 \mathrm{E}-06$ & 101.26 \\
\hline 5 & 45 & 0 & 60 & 75 & 140 & $3.61 \mathrm{E}-04$ & 68.84 \\
\hline 6 & 45 & 5 & 45 & 85 & 105 & $2.5833 \mathrm{E}-04$ & 71.75 \\
\hline 7 & 45 & 10 & 90 & 55 & 70 & $2.1875 \mathrm{E}-04$ & 73.20 \\
\hline 8 & 45 & 15 & 75 & 65 & 35 & $1.7083 \mathrm{E}-04$ & 75.34 \\
\hline 9 & 55 & 0 & 75 & 85 & 70 & $5.93 \mathrm{E}-05$ & 84.54 \\
\hline 10 & 55 & 5 & 90 & 75 & 35 & $2.7204 \mathrm{E}-04$ & 71.31 \\
\hline 11 & 55 & 10 & 45 & 65 & 140 & $9.8388 \mathrm{E}-04$ & 60.14 \\
\hline 12 & 55 & 15 & 60 & 55 & 105 & $9.7039 \mathrm{E}-05$ & 80.26 \\
\hline 13 & 65 & 0 & 90 & 65 & 105 & $2.89 \mathrm{E}-04$ & 70.77 \\
\hline 14 & 65 & 5 & 75 & 55 & 140 & $1.2075 \mathrm{E}-03$ & 58.36 \\
\hline 15 & 65 & 10 & 60 & 85 & 35 & $1.7500 \mathrm{E}-03$ & 55.14 \\
\hline 16 & 65 & 15 & 45 & 75 & 70 & $1.4900 \mathrm{E}-03$ & 56.54 \\
\hline
\end{tabular}




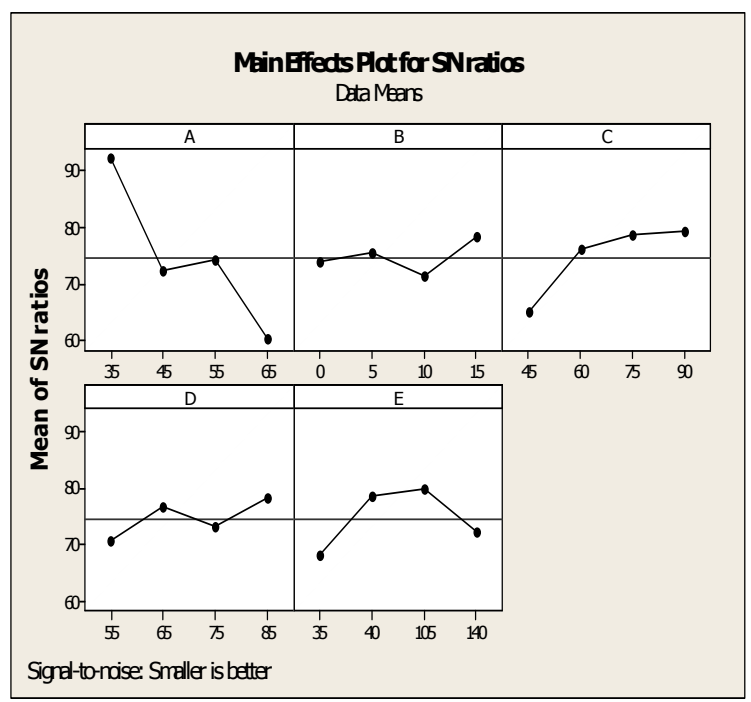

Fig. 4. Effect of control factors on erosion rate

\section{ANOVA and the Effects of Factors}

Table IV shows the ANOVA result for the erosion rate of composites under erosion wear. This analysis is undertaken for a level of confidence of significance of $5 \%$. From Table IV, it is observed that the impact velocity, impingement angle, stand-off distance and fiber loading have greater effect on erosion rate. However, erodent temperature shows least effect on erosion rate.

TABLE IV: ANOVA FOR EROSION RATE

\begin{tabular}{|c|c|c|c|c|c|c|}
\hline Source & DF & Seq SS & Adj SS & Adj MS & F & p \\
\hline A & 3 & 1756.31 & 1756.31 & 1756.31 & 18.67 & 0.002 \\
\hline B & 3 & 18.43 & 18.43 & 18.43 & 0.20 & 0.667 \\
\hline C & 3 & 413.83 & 413.83 & 413.83 & 4.40 & 0.062 \\
\hline D & 3 & 73.44 & 73.44 & 73.44 & 0.78 & 0.398 \\
\hline E & 3 & 6.40 & 6.40 & 6.40 & 0.07 & 0.800 \\
\hline Error & 0 & 940.90 & 940.90 & 94.09 & & \\
\hline Total & 15 & 3209.32 & & & & \\
\hline
\end{tabular}

\section{CONCLUSIONS}

The experimental investigation on the erosion behavior of short bamboo fiber reinforced epoxy composites filled with copper slag leads to the following conclusions:

1) Erosion characteristics of these composites are successfully analyzed using Taguchi experimental design. Taguchi method provides a simple, systematic and efficient methodology for the analysis of the control factors. Significant factors affecting the erosion rate of composites are identified through successful implementation of ANOVA. It is found that for the current study the factors like impact velocity, impingement angle, stand-off distance and fiber loading have greater effect on erosion rate. However, erodent temperature shows least effect on erosion rate.

2) This study reveals the semi-ductile response for all composites irrespective of copper slag content. The peak erosion rate is found to be occurring at $60^{\circ}$ impingement angle. Also, the erosion rate of all these composites is also affected by the erodent temperature.

3) Possible use of these composites such as pipes carrying coal dust, industrial fans, helicopter fan blades, desert structures, low cost housing etc. is recommended.

\section{ACKNOWLEDGEMENT}

The corresponding author is grateful to Department of Science and Technology, Govt. of India for providing the financial support for this research work under the research project Ref. No. SR/FT/ET-026/2009.

\section{REFERENCES}

[1] E. Vazquez, A. Roca, A. Lopez-Soler, J. L. Fernandez-Turiel, X. Querol, and M.T. Felipo, "Physico-chemical and mineralogy characterization of mining wastes used in construction," Waste Materials in Construction, Studies in Environmental Science, vol. 48, pp. 215-223, 1991.

[2] M. Kamon and T. Katsumi, "Civil engineering use of industrial waste in Japan," in Proceedings of the International Symposium on Developments in Geotechnical Engineering, Balasubramaniam, A.S. ed., Bangkok, Thailand, 1994, pp. 265-278.

[3] J. Hartlén, M. Carling, and Y. Nagasaka, "Recycling or reuse of waste materials in geotechnical applications" in Proceedings of the Second International Congress on Environmental Geotechnics, Kamon, M. ed., Osaka, Japan, 1997, pp. 1493-1513.

[4] R. Sarsby, Environmental Geotechnics, Thomas Telford Ltd., London, UK, 2000, pp.584.

[5] U-M. Mroueh, J. Laine-Ylijoki, and P. Eskola, "Life-cycle impacts of the use of industrial by-products in road and earth construction," Waste Management Series, vol. 1, pp. 438-448, 2000.

[6] W. G. Davenport, M. King, M. Schlesinger, and A. K. Biswas, Extractive metallurgy of copper, 4th ed. Pergamon Press, 2002, pp. 460.

[7] R. J. Collins and S. K. Ciesielski, Recycling and Use of Waste Materials and By-Products in Highway Construction. National Cooperative Highway Research Program Synthesis of Highway Practice 199, Transportation Research Board, Washington, DC, 1994.

[8] T. Ayano and K. Sakata, "Durability of concrete with copper slag fine aggregate," in Proceedings of the fifth CANMET/ACI international conference on durability of concrete, SP-192, American Concrete Institute, 2000, pp.141-158.

[9] W. Moura, A. Masuero, D. Dal Molin, and A. Vilela, "Concrete performance with admixtures of electrical steel slag and copper concerning mechanical properties," in Proceedings of the 2nd CANMET/ACI international conference on high-performance concrete, SP-186, American Concrete Institute, 1999, pp.81-100.

[10] A. Taeb and S. Faghihi, "Utilization of copper slag in the cement industry," ZKG International, vol. 55, no. 4, pp. 98-100, 2002.

[11] K. S. Al-Jabri, R. Taha, and M. Al-Ghassani, "Use of copper slag and cement by-pass dust as cementitious materials," Cement, Concrete and Aggregates, vol. 24, no. 1, pp. 7-12, 2002.

[12] N. M. Barkoula and J. Karger-Kocsis, "Review-processes and influencing parameters of the solid particle erosion of polymers and their composites," J. Mater. Sci., vol. 37, pp. 3807-3820, 2002.

[13] A. P. Harsha, U. S. Tewari, and B. Venkataraman, "Solid particle erosion behaviour of various polyaryletherketone composites," Wear, vol. 254, no. 7-8, pp. 693-712, 2003.

[14] S. Biswas, A. Satapathy, and A. Patnaik, "Erosion Wear Behaviour of Polymer Composites: A Review," Journal of Reinforced Plastics and Composites, vol. 29, no. 19, pp. 2898-2924, 2010.

[15] A.W. Ruff and L. K. Ives, "Measurement of solid particle velocity in erosive wear," Wear, vol. 35, no. 1, 195-199, 1975.

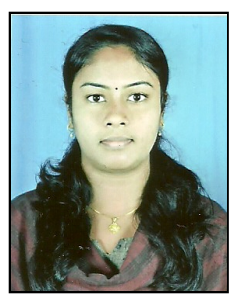

Sandhyarani Biswas was born 1981, graduated in Manufacturing Science and Engineering from University College of Engineering, Burla in the year 2004. She completed her Ph.D. in the area of Composite Materials form National Institute of Technology (NIT), Rourkela, India in the year 2010.

She is working as assistant professor in the Department of Mechanical Engineering at the National Institute of Technology, Rourkela, India. She has been engaged in active research in the field of composite materials and tribology for the last couple of years. She has more than 40 research papers in various nations and international journals. She has also presented 42 research papers related to composite materials and optimization techniques at various national and international conferences held in India and abroad. 